\title{
Inter-Relationship of Major Sectors of Indian Economy: Co-Integration and Granger Causality Analysis
}

\author{
Avinash CS ${ }^{1}$., B.L. Patil ${ }^{1}$ and Ravi Dupdal ${ }^{2}$ \\ ${ }^{1}$ Department of Agricultural Economics, University of Agricultural Sciences, Dharwad, Karnataka, India \\ ${ }^{2}$ ICAR-Indian Institute of Soil and Water Conservation, Research Centre, Ballari-583104, Karnataka, India \\ *Corresponding author: avinashnaik808@gmail.com
}

\begin{abstract}
The study has investigated country's GDP integration across five major sectors of Indian economy, viz. agriculture, service, industry, manufacturing and mining and quarrying by adopting Johansen's multivariate co-integration approach. The study has confirmed the presence of co-integration, implying the long-run GDP association among the Sectors. To get the additional evidence as to whether and in which direction GDP transmission is occurring between the sector pairs, Granger causality test has been used, which has confirmed agriculture and service has the bidirectional cause, service has unidirectional cause on manufacturing, industry has unidirectional cause on service and agriculture has unidirectional cause on manufacturing so this sector has the significant effect. The major implication of the study is for the designing of a network of GDP interaction among the major sectors of Indian economy and to know in which direction one sector is influencing another.
\end{abstract}

Keywords: Unit root test, Johansen's multivariate co-integration, Granger causality test, Indian economy, Gross Domestic Product

The economy of India is a developing mixed economy. It is the world's sixth-largest economy by nominal GDP and the third-largest by purchasing power parity (PPP). The country ranks $141^{\text {st }}$ in per capita GDP (nominal) with $\$ 1723$ and $123^{\text {rd }}$ in per capita GDP (PPP) with $\$ 6,616$ as of 2016. After 1991 economic liberalization, India achieved 6-7 per cent average GDP growth annually. In FY 2015 and 2017, India's economy became the world's fastest growing major economy surpassing China. India has one of the fastest growing service sectors in the world with an annual growth rate above 9 per cent since 2001, which contributed to 57 per cent of GDP in 2012-13. India has become a major exporter of IT services, Business Process Outsourcing (BPO) services, and software services with $\$ 154$ billion revenue in FY 2017. This is the fastest-growing part of the economy. The IT industry continues to be the largest private-sector employer in India. India is the third-largest startup hub in the world with over 3,100 technology start-ups in 2014-15. The agricultural sector is the largest employer in India's economy but contributes to a declining share of its GDP (17\% in 2013-14). India ranks second worldwide in farm output. The industry sector has held a steady share of its economic contribution (26\% of GDP in 2013-14). The Indian automobile industry is one of the largest in the world with an annual production of 21.48 million vehicles (mostly two and three-wheelers) in 2013-14. India had $\$ 600$ billion worth retail market in 2015 and is one of world's fastest growing e-commerce markets (Economic survey report 2017).

India is facing many economic challenges mainly low per capita income (1861.5 US\$), excessive dependence of agriculture and primary producing (56\% population), high rate of population growth $(2.17 \%)$ existence of chronic unemployment and under-employment $(8.28 \%)$, poor rate of capital formation, inequality in the distribution of wealth, low level technology and under-utilization of 
natural resources. Still India's internal trade to GDP is comparable to that of the other large countries and is very different from the caricature of a barrierriddled economy. Interestingly, demonetization decision and the arrival of the GST system as a backdrop for the slowdown of growth, both acknowledge that the two measures have had an enormous disruptive impact. However, the Government has maintained that GST will turn out to be a huge plus factor in driving economic growth once the system settles down to a near glitch-free performance.

\section{MATERIAL AND METHODS}

The data on GDP growth rate of major sectors like agriculture, service, industry, manufacturing and mining and quarrying of Indian economy for the year 1955 to 2017 has been collected from Ministry of Statistics and Programme Implementation, Government of India. All the series were transformed into natural log-form to eliminate variations in movement due to level differences. The analytical techniques used in the study are described below.

Augmented Dickey-Fuller (ADF): Unit Root Test, an implicit assumption in Johansen's co-integration approach is that the variables should be nonstationary at the level, but stationary after first differencing. The Augmented Dickey-Fuller test is utilized to check the order of integration by using the model (1):

$$
\Delta Y_{t}=\alpha+\delta T+\beta_{1} Y_{t-1}+\sum_{i=1}^{p} \beta_{1} \Delta Y_{t-1}+\varepsilon_{t}
$$

where, $\Delta \mathrm{Y}_{\mathrm{t}}=\mathrm{Y}_{\mathrm{t}}-\mathrm{Y}_{\mathrm{t}-1^{\prime}} \Delta \mathrm{Y}_{\mathrm{t}-1}=\mathrm{Y}_{\mathrm{t}-1}-\mathrm{Y}_{\mathrm{t}-2^{\prime}}$ and $\Delta \mathrm{Y}_{\mathrm{t}-2}$ $=\mathrm{Y}_{\mathrm{t}-2}-\mathrm{Y}_{\mathrm{t}-3^{\prime}}$ etc., $\varepsilon_{\mathrm{t}}$ is pure white noise term, $\alpha$ is the constant-term, $\mathrm{T}$ is the time trend effect, and $p$ is the optimal lag value, which is selected on the basis of Schwartz information criterion1 (SIC). The null hypothesis is that $\beta_{1}$, the coefficient of $Y_{t-1}$ is zero. The alternative hypothesis is: $\beta_{1}<0$. A non-rejection of null hypothesis suggests that the time series under consideration is non-stationary (Gujarati, 2010).

\section{Co-integration Analysis Using Johansen Methodology}

The Johansen procedure examines a vector auto regressive (VAR) model of $Y t$, an $(n \times 1)$ vector of variables that are integrated of the order one $-\mathrm{I}(1)$ time series. This VAR can be expressed as Equation (2)

$$
\Delta Y_{t}=\mu+\sum_{i=1}^{p-1} \Gamma_{i} Y_{t-1}+\Pi Y_{t-1}+\varepsilon_{t}
$$

where, $\Gamma$ and $\Pi$ are matrices of parameters, $p$ is the number of lags (selected on the basis of Schwarz information criterion), $\varepsilon \mathrm{t}$ is a $(\mathrm{n} \times 1)$ vector of innovations. The presence of at least one co-integrating relationship is necessary for the analysis of long-run relationship of the GDP to be plausible. To detect the number of co-integrating vectors, Johansen proposed two likelihood ratio tests: trace test and maximum eigen-value test, shown in Equations (3) and (4), respectively.

$$
\begin{aligned}
& \mathrm{J}_{\text {trace }}=-T \sum_{i=r+1}^{n} \ln \left(1-\hat{\lambda}_{i}\right) \\
& \mathrm{J}_{\text {Max }}=-T \ln \left(1-\hat{\lambda}_{r}+1\right)
\end{aligned}
$$

where, $\mathrm{T}$ is the sample size and $\hat{\lambda}_{i}$ is the $\mathrm{i}^{\text {th }}$ largest canonical correlation. The trace test examines the null hypothesis of $\mathrm{r}$ co-integrating vectors against the alternative hypothesis of $n$ co-integrating vectors. The maximum eigen-value test, on the other hand, tests the null hypothesis of $\mathrm{r}$ co-integrating vectors against the alternative hypothesis of $r+1$ co-integrating vectors (Hjalmarsson and Osterholm, 2010).

Granger Causality Test: The Granger causality test conducted within the framework of a VAR model is used to test the existence and the direction of longrun causal GDP relationship between the Sectors (Granger, 1969). It is a F-test that checks whether changes in one GDP series affect another GDP Series. Taking the causality relationship between Agriculture and Service Sector

Example, the test was based on the following pairs of OLS regression equations through a bivariate VAR:

- $P \ln$ Agriculture $_{\mathrm{t}}=\sum_{i=1}^{m} \alpha i P \ln$ Agriculture $_{\mathrm{t}-\mathrm{I}}+$ $\sum_{i=1}^{m} \beta j$ Pln Service $\mathrm{t}-\mathrm{j}+\mathrm{e}_{1 \mathrm{t}}$

- $P \ln$ Service $_{\mathrm{t}}=\sum_{i=1}^{m} \alpha i$ Pln Service $_{\mathrm{t}-1}+\sum_{i=1}^{m} \beta j P \ln$ Agriculture $_{\mathrm{t}-\mathrm{j}}+\mathrm{e}_{1 \mathrm{t}}$

where, $P \ln$ stands for GDP series in logarithm form and $t$ is the time trend variable. The subscript 
stands for the number of lags of both variables in the system. The null hypothesis in Eq. (5), i.e. H0: $\beta 1=\beta 2=\ldots=\beta \mathrm{j}=0$ against the alternative, i.e., $\mathrm{H} 1$ : Not H0, is that Pln Agriculture does not Granger cause Pln Service. Similarly, testing H0: $\delta 1=\delta 2=\ldots$ $=\delta \mathrm{j}=0$ against $\mathrm{H} 1$ : Not $\mathrm{H} 0$ in Eq. (6) is a test that $\mathrm{Pln}$ Service does not Granger cause Pln Agriculture. In each case, a rejection of the null hypothesis will imply that there is Granger causality between the variables (Gujarati, 2010).

\section{RESULTS AND DISCUSSION}

The results of the Augmented Dickey-Fuller (ADF) unit root test applied at level and first difference to the logarithmically transformed GDP of Major sector are given in Table 1. The empirical evidence suggests that GDP series had unit root problem at their level form. The null hypothesis of the unit root at level form cannot be rejected for all GDP series as the absolute values of the ADF statistics are well below 5 per cent critical values of the test statistics.
Thus, it is concluded that all the GDP series are non-stationary at their level forms. In order to test the level or number of unit roots in the data, a unit root test of first difference was conducted, which showed the number of unit roots to be equal to one, since the data became stationary after the first difference as absolute values of the ADF statistics were now greater than 5 per cent critical values of the test statistics. With the proof that the GDP series were non-stationary and integrated of the order 1 , test for co-integration among the selected Indian economy using Johansen's maximum likelihood approach was applied.

The results of Johansen's maximum likelihood tests (maximum eigen-value and trace test) are given in Table 2. To check the first null hypothesis whether the variables were not co-integrated $(r=0)$, trace and eigen-value statistics were calculated, both of which rejected the null hypotheses as maximum eigen-value and trace test statistics values were higher than 5 per cent critical values and accepted

Table 1: Augmented Dickey-Fuller (ADF) unit root test results of major sectors of Indian Economy

\begin{tabular}{ccccc}
\hline Market & At level/ First Difference & T-Cal & (Prob $\left.^{*}\right)$ & Remarks \\
\hline Agriculture & $\ln \mathrm{A}$ & -1.02 & $(0.0659)$ & Non-Stationary \\
& $\Delta \ln \mathrm{A}$ & -.9 .56 & $(0.0000)$ & Stationary \\
Industry & $\ln \mathrm{I}$ & -2.36 & $(0.2075)$ & Non-Stationary \\
& $\Delta \ln \mathrm{I}$ & -7.42 & $(0.0000)$ & Stationary \\
Manufacturing & $\ln \mathrm{M}$ & -2.45 & $(0.2324)$ & Non-Stationary \\
& $\Delta \ln \mathrm{M}$ & -6.79 & $(0.0000)$ & Stationary \\
Mining & $\ln \mathrm{m}$ & -.1 .43 & $(0.2757)$ & Non-Stationary \\
& $\Delta \ln \mathrm{m}$ & -7.94 & $(0.0000)$ & Stationary \\
\multirow{2}{*}{ Service } & $\ln \mathrm{m}$ & -0.012 & $(0.0854)$ & Non-Stationary \\
& $\Delta \ln \mathrm{m}$ & -7.42 & $(0.0000)$ & Stationary \\
\hline
\end{tabular}

Notes: 1 . The asterisks ** indicate that unit root at level or in the first differences were rejected at 1 per cent as well as at 5 per cent significance; The (prob.*) denotes MacKinnon (1996) one-sided p-values; Note 2: 'In' denotes GDP in logarithmic form and $\triangle$ ln denotes the GDP Series in logarithm form after first difference.

Table 2: Results of Johansen's Multiple Co-integration Analysis for Major Sector of Indian economy

\begin{tabular}{|c|c|c|c|c|}
\hline \multicolumn{5}{|c|}{ Unrestricted Co-integration Rank Test (Maximum Eigenvalue) } \\
\hline Hypothesized & & Max-Eigen & 0.05 & \\
\hline No. of CE(s) & Eigenvalue & Statistic & Critical Value & Prob.** \\
\hline None $^{*}$ & 0.574493 & 51.26847 & 33.87687 & 0.0002 \\
\hline At most $1^{*}$ & 0.408678 & 31.52364 & 27.58434 & 0.0148 \\
\hline At most $2 *$ & 0.338726 & 24.81521 & 21.13162 & 0.0144 \\
\hline At most $3^{*}$ & 0.263903 & 18.38360 & 14.26460 & 0.0106 \\
\hline At most $4^{*}$ & 0.125557 & 8.050101 & 3.841466 & 0.0046 \\
\hline
\end{tabular}

Max-eigenvalue test indicates 5 co-integrating eqn (s) at the 0.05 level; * denotes rejection of the hypothesis at the 0.05 level; **MacKinnonHaug-Michelis (1999) p-values. 
the alternative of one or more co-integrating vectors. Similarly, the null hypotheses: $r \leq 1, r \leq 2$ and $r \leq 3$ from both statistics were rejected against their alternative hypotheses of $r \geq 1, r \geq 2$ and $r$ $\geq 3$, respectively. The null hypothesis $r \leq 4$ from both the tests (trace test and maximum eigenvalue test) were accepted and their alternative hypotheses $(r=5)$ were rejected as the trace value and maximum eigen-value were well below than their corresponding critical values at 5 per cent level of significance. Both these tests confirmed that all the five selected major sectors of Indian economy had 4 co-integrating vectors out of 5 co-integrating equations, indicating that they are well integrated and GDP Signals are transferred from one sector to the other sector ensuring efficiency. Thus, Johnson co-integration test has shown that even though the selected sectors of economy in India have different features and are spatially segmented, they are wellconnected in terms of GDP, demonstrating that the selected major sectors of Indian economy have long-run GDP linkage across them.

After finding co-integration among different major sectors of economy, granger causality was also estimated between the selected pairs of the major sectors in India. The granger causality shows the direction of GDP formation between two sectors. The results of granger causality tests are presented in Table 3. The Johansen's multiple co-integration results reveal that all the five sectors are well

Table 3: Pair-wise Granger causality in major Sectors

\begin{tabular}{|c|c|c|c|c|c|}
\hline $\begin{array}{ll}\text { Sl. } \\
\text { No. }\end{array}$ & Null Hypothesis & F-statistics & Probability & $\begin{array}{l}\text { Granger } \\
\text { cause }\end{array}$ & Direction \\
\hline \multirow[t]{2}{*}{1} & $\begin{array}{l}\text { MINING_AND_QUARYING does not Granger Cause } \\
\text { SERVICE }\end{array}$ & 0.65293 & 0.5244 & NO & None \\
\hline & $\begin{array}{l}\text { SERVICE does not Granger Cause MINING_AND_ } \\
\text { QUARYING }\end{array}$ & 0.91451 & 0.4066 & NO & \\
\hline \multirow[t]{2}{*}{2} & MANUFACTURING does not Granger Cause SERVICE & 0.71239 & 0.4949 & No & Unidirectional \\
\hline & SERVICE does not Granger Cause MANUFACTURING & 2.91567 & $0.0624^{* *}$ & Yes & \\
\hline \multirow[t]{2}{*}{3} & INDUSTRY does not Granger Cause SERVICE & 2.36403 & $0.1000^{*}$ & yes & Unidirectional \\
\hline & SERVICE does not Granger Cause INDUSTRY & 1.78345 & 0.1775 & No & \\
\hline \multirow[t]{2}{*}{4} & AGRICULTURE does not Granger Cause SERVICE & 2.91268 & $0.0626^{* *}$ & Yes & Bidirectional \\
\hline & SERVICE does not Granger Cause AGRICULTURE & 2.44860 & $0.0640^{* *}$ & No & \\
\hline \multirow[t]{2}{*}{5} & $\begin{array}{l}\text { MANUFACTURING does not Granger Cause MINING_AND_ } \\
\text { QUARYING }\end{array}$ & 0.97030 & 0.3852 & No & None \\
\hline & $\begin{array}{l}\text { MINING_AND_QUARYING does not Granger Cause } \\
\text { MANUFACTURING }\end{array}$ & 0.33570 & 0.7103 & No & \\
\hline \multirow[t]{2}{*}{6} & $\begin{array}{l}\text { INDUSTRY does not Granger Cause MINING_AND_ } \\
\text { QUARYING }\end{array}$ & 1.33510 & 0.2714 & No & None \\
\hline & $\begin{array}{l}\text { MINING_AND_QUARYING does not Granger Cause } \\
\text { INDUSTRY }\end{array}$ & 0.56752 & 0.5702 & No & \\
\hline \multirow[t]{2}{*}{7} & $\begin{array}{l}\text { AGRICULTURE does not Granger Cause MINING_AND_ } \\
\text { QUARYING }\end{array}$ & 1.21642 & 0.3040 & No & None \\
\hline & $\begin{array}{l}\text { MINING_AND_QUARYING does not Granger Cause } \\
\text { AGRICULTURE }\end{array}$ & 0.01334 & 0.9867 & No & \\
\hline \multirow[t]{2}{*}{8} & INDUSTRY does not Granger Cause MANUFACTURING & 1.54239 & 0.2228 & No & None \\
\hline & MANUFACTURING does not Granger Cause INDUSTRY & 0.57680 & 0.5650 & No & \\
\hline \multirow[t]{2}{*}{9} & AGRICULTURE does not Granger Cause MANUFACTURING & 3.16889 & $0.0497^{* *}$ & Yes & Unidirectional \\
\hline & MANUFACTURING does not Granger Cause AGRICULTURE & 0.65342 & 0.5242 & No & \\
\hline \multirow[t]{2}{*}{10} & AGRICULTURE does not Granger Cause INDUSTRY & 1.97603 & 0.1482 & No & None \\
\hline & INDUSTRY does not Granger Cause AGRICULTURE & 0.43719 & 0.6480 & No & \\
\hline
\end{tabular}

Notes: The lags of the dependent variable used to obtain white-noise residuals were determined using the Schwarz Information Criterion (SIC). ** denotes rejection of the null hypothesis at 5 per cent level of significance. 
integrated and well connected in term of GDP in the long run. Similarly, the pair wise Granger causality analysis reveals that agriculture and service has the bidirectional cause, service has unidirectional cause on manufacturing, industry has unidirectional cause on service and agriculture has unidirectional cause on manufacturing so this sector has significant effect (Fig. 1).

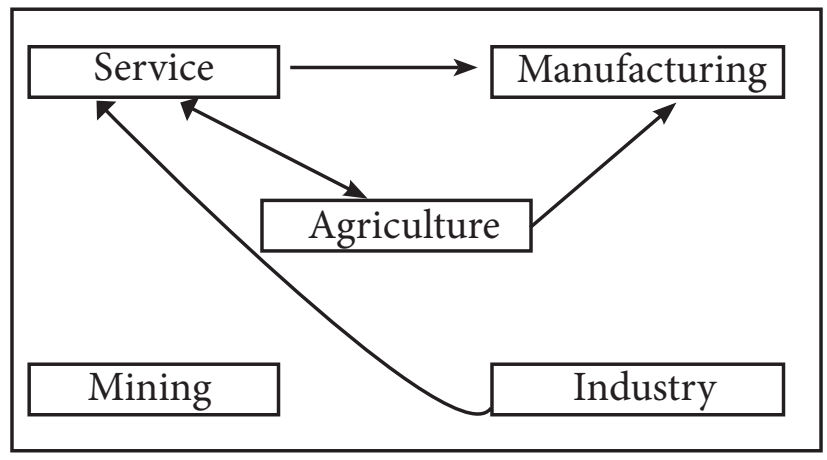

Fig. 1: Granger causality directions between the Sector

\section{CONCLUSION}

Indian economy is comprised of many sectors. Among them agriculture, service, industry, manufacturing and mining and quarrying sectors are the major sectors of the Indian economy, because these sectors contribute the highest GDP to the total GDP of the Indian Economy. Agriculture GDP is decreasing over the years when compared to other sectors, which is the most concerning issue pertaining to Indian economy because 56 per cent of the Indian population is dependent on agriculture as it is a backbone of India. When we observe the findings of analysis, agriculture and service sector has the bidirectional cause that means a change in GDP of agriculture sector which will have influence on service and vice versa. It is a fact that service sector is contributing the highest GDP (57\%) to the total GDP of the economy and it is expected to contribute more in the ensuing years. Whereas, the manufacturing sector growth has declined by 1.2 per cent in 2016-17 when compared to last year (2015-16), which is also a most focused growth to Indian GDP. Agriculture is performing better in terms of magnitude but in terms of GDP it is very less i.e., 13.9 per cent (56 per cent in 1960) so it is clear that the service is overtaking all the other sectors in GDP contribution to the economy but agriculture is primary in India so it is important to uplift the GDP growth of agriculture in the earning years by investing more in the development of infrastructure. This will generate more Gross Capital and Gross Value Added to make our country stand as a global leader.

\section{REFERENCES}

Anonymous (b), 2017, Economic Survey Report government of India ministry of finance department of economic affairs economic division, pp. 1-277.

Anonymous, 2017, Reserve Bank of India report, Government of India ministry of finance., pp. 1-355.

Fayaz Ahmad Beag. and Naresh Singla, 2014. Co-integration, causality and impulse response analysis in major apple markets of India, Agricultural Economics Research Review, 27(2): 289-298.

Ghafoor, A., Mustafa, K., Mushtaq, K. and Abedulla, 2008. Co-integration and causality: An application to major mango markets in Pakistan. Lahore Journal of Economics, 14(1): 85-113.

Ghosh, M. 2009. Spatial integration of wheat markets in India: Evidence from co-integration tests. Oxford Development Studies, 31(2): 159-171.

Granger, C.W.J. 1969. Investigating causal relations by econometric models and cross-spectral methods. Econometrica, 37(3): 424-38.

Gujarati, D. 2010. Econometrics by Example. Macmillan Publishers, London.

Hjalmarsson, E. and Osterholm, P. 2010. Testing for cointegration using the Johansen methodology when variables are near-integrated. Empirical Economics, 39(1): 51-76. 
